\title{
Succession of Oribatid Mites (Acari: Cryptostigmata) Community in Soil and in Needle Litter after Reforestation of Cryptomeria japonica in Japan
}

\author{
Kenji FUKUYAMA ${ }^{1}$ and Masamichi ITO ${ }^{2}$ \\ ${ }^{1}$ Hokkaido Research Center, Forestry and Forest Products Research Institute, \\ Hitsujigaoka 1, Sapporo, 062 Japan \\ ${ }^{2}$ Division of Forest Biology, Forestry and Forest Products Research Institute, \\ Matunosato 1, Ibaraki, 305 Japan
}

(Accepted 13 April 1992)

\begin{abstract}
Fukuyama, K. and M. Ito, 1992. Succession of oribatid mites (Acari: Cryptostigmata) Community in soil and in needle litter after reforestation of Cryptomeria japonica in Japan. J. Acarol. Soc. Jpn., 1(2): $113-126$.
\end{abstract}

A comparison of oribatid mite communities inhabiting soil and needle litter in differently aged (6, 13, 38 and 80 year old) plantations of Cryptomeria japonica D. Don was carried out at Mt. Tsukuba, in central Japan. The density of the microarthropods was highest in the youngest stand and lowest in the 38-year-old. The distribution pattern of dominant species of oribatid mite among study sites was divided into 4 types. Type 1 was related to the mass of the soil organic material. Type 2 was related to soil humidity. Type 3 was related to the mass of needle litter. And type 4 was related to the age after reforestation. Exchange between closely related species occurred among differently aged forests. Four oribatid species were recovered from the needle litter of $C$. japonica. Rhysotritia ardua (Koch) and Hoplophthiracarus foveolatus Aoki are dominant species inhabiting in the needle litter.

Key Words: Cryptostigmata, Cryptomeria japonica, succession, reforestation, soil, borer

\section{INTRODUCTION}

Silvicultural practices such as clear cutting have an effect on soil fauna (Karppinen, 1957; Huhta et al., 1967; Fukuyama, 1974; Takahashi and Niijima, 1988). The secondary succession of soil fauna in natural forests ordinarily starts just after clear-cutting (Huhta et al., 1969; Huhta, 1976). But, artificial reforestation may result in a different succession process. The information to be gained from the soil community succession after reforestation is useful when constructing a forest management system that takes environmental conservation into consideration.

In Japan, there have been few studies on succession process of the soil organic fauna after reforestation (Watanabe, 1973). Oribatid mites are known to be one of the major 
saprophagous organisms found in forest soil, with various groups of oribatid mites also boring into coniferous needle litter, twigs and decay wood (Wallwork, 1976; Aoki, 1973; Lions and Goubière, 1988; Kaneko, 1990), but these boring species are difficult to recover using the Tullgren funnels. An investigation on the succession of oribatid mites in soil and boring in needle litter after reforestation of $C$. japonica plantation have been carried out using the Tullgren funnels and direct observation technique in Japan. In spite of the long term study of the succession on the same stand, the comparative study was carried out among differently aged plantations which were situated close to each other and had the same topographical and geological conditions.

\section{MATERIALS AND METHODS}

Study site: Four study sites were selected at Mt. Tsukuba in Ibaraki Pref., in central Japan. The study sites were situated close to each other and the longest distance between them was about $400 \mathrm{~m}$. The altitude was about $300 \mathrm{~m}$ above the sea level and the sites were on the northern slope.

Site I: The 80-year-old cryptomeria plantation was clear-cut in 1983 and C. japonica was planted in 1984 . The tree age was 6 -year-old at investigation period. The average tree height was about $2-2.5 \mathrm{~m}$ and the $\mathrm{DBH}$ was about $3 \mathrm{~cm}$. The vegetation on the forest floor was dominated by Miscanthus sinensis Anderss. and Pleioblastus chino Makino. The other minor vagetation species were Rubus palmatus Thunb. and Carpinus tschonoskii Maxim. The angle of the slope was at an angle of 20 degrees.

SiteII: $C$. japonica were planted in 1977. The tree age was 13-year-old, the average tree height was about $6 \mathrm{~m}$ and the $\mathrm{DBH}$ was about $9 \mathrm{~cm}$. The dominant vegetation in the forest floor was also $M$. sinensis. The other minor vegetation were Castanea crenata Sieb. et Zucc., Quercus serrata Murray, Aucuba japonica Thunb., Eurya japonica Thunb., Lindera umbellata Thunb. and $R$. palmatus. The angle of the slope was at an angle of 28 degrees.

Site III: C. japonica were planted in 1952. The tree age was 38-year-old and the DBH was about the average tree height was about $15 \mathrm{~m}$ and the DBH was about $16 \mathrm{~cm}$ with little vegetation (A. japonica, Hydrangea involucrata and Hedera rhombea Bean) on the forest floor. The slope angle was at an angle of 21 degrees.

Site IV: C. japonica were planted in 1910. the tree age was 80 -year-old and the average tree height was about $25 \mathrm{~m}$ and the DBH was about $30 \mathrm{~cm}$. The dominant species of vegetation on the forest floor were $A$. japonica, $H$. involucrata and the minor vegetation were H. rhomea, Neolitsea sericea Koidzumi and Polygonum filiforme Thunb. The slope angle was at an angle of 19 degrees.

Sampling: Ten core samples $\left(20 \mathrm{~cm}^{2} \times 5 \mathrm{~cm}\right)$ were collected from each study site on both November 15 and November 22 in 1990. The soil micro-arthropods were extracted by using the Tullgren funnels during 72 hours in the laboratory. Five soil samples after being treated with the Tullgren funnels were randomly selected and the needles of $C$. japonica litter were separated from them. The needls were dissected by a pincette and oribatid mites boring in the needles were collected under a stereoscopic microscope. 


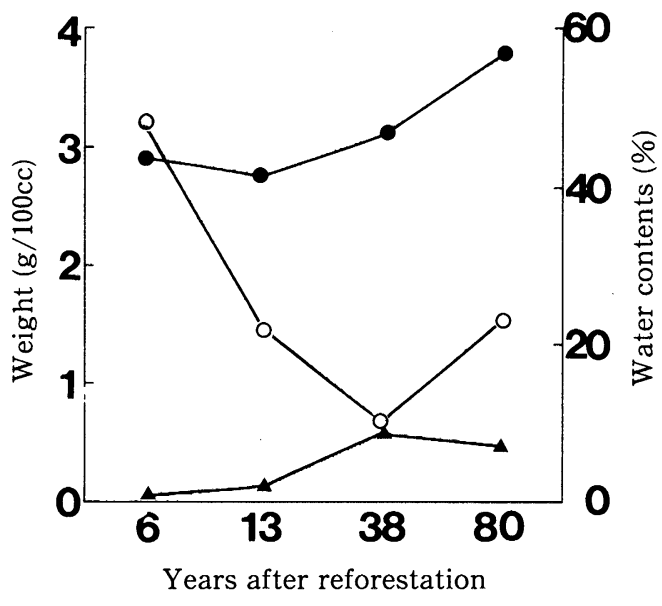

Fig. 1. Litter weights and water contents of study sites.

O: Dry weight of litter except for needles, $\mathbf{\Delta}$ : Dry weight of needle litter of $C$. japonica,

O: Water contents.

Wet and dry weights of soil samples were measured. Litter weights of C. japonica and the others were also measured (Fig. 1).

\section{RESULTS}

\section{1 ) Comparison of soil micro-arthropod groups among the study sites}

Twenty two order or sub-order groups of micro-arthropods were collected using the Tullgren funnels, with the dominant groups being mites and Collembola. Total individual number of mites and Collembola was highest in the 6-year-old stand (site I) and gradually decreased to the 38-year-old stand (site III). It increased again in the 80 -year-old forest (site IV) (Fig. 2). The relative abundances of Hymenoptera (ants) and Protura gradually decreased after reforestation. On the contrary, those of Diptera, Collembola and Araneae gradually increased (Figs. 2 and 3). The relative abundance of mites did not fluctuated markedly after reforestation (Fig. 2).

\section{2 ) Comparison of oribatid mites among the study sites}

Forty nine identified and 25 unidentified oribatid species were collected using the Tullgren funnels (Table 1). Total individual number of oribatid mites was highest in the 6-year-old stand (site I) and gradually decreased to the 38-year-old stand (site III). It increased again in the 80 -year-old forest (site IV) (Fig. 4). But the species number of oribatid mites was least in the 80 -year-old forest (Fig. 4). The species diversity index, Sheldon's $\mathrm{e}^{\mathrm{H}^{\prime}}$ (Sheldon, 1969), shows that species diversity was also highest in the 6year-old forest and it was lowest in the 38-year-old forest (Fig. 4). But the total individual number oribatid mites, if being included the boring species into the cryptomeria needle litter, increased in the 38-year-old forest (Fig. 4).

The similarity of the community structure of oribatid mites among study sites was 


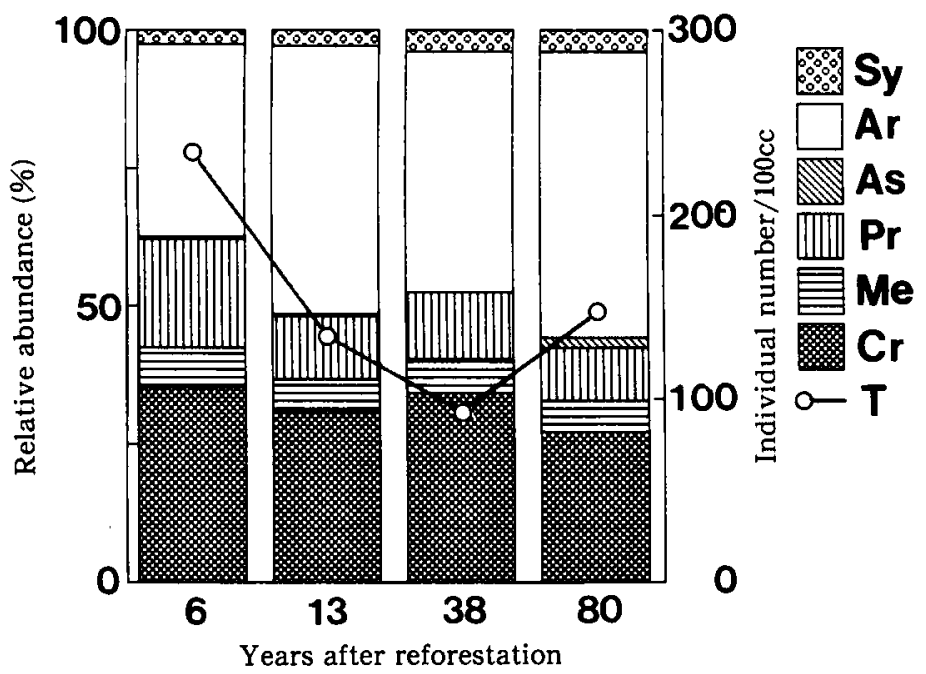

Fig. 2. Succession of soil mites and Collembola after reforestation.

Bar graphs mean population ratios among the groups. Line graphs mean total number of mites and Collembola. Sy: Symphypleona (Collembola), Ar: Arthropleona (Collembola), As: Astigmata, Pr: Prostigmata, Me: Mesostigmata, Cr: Cryptostigmata.

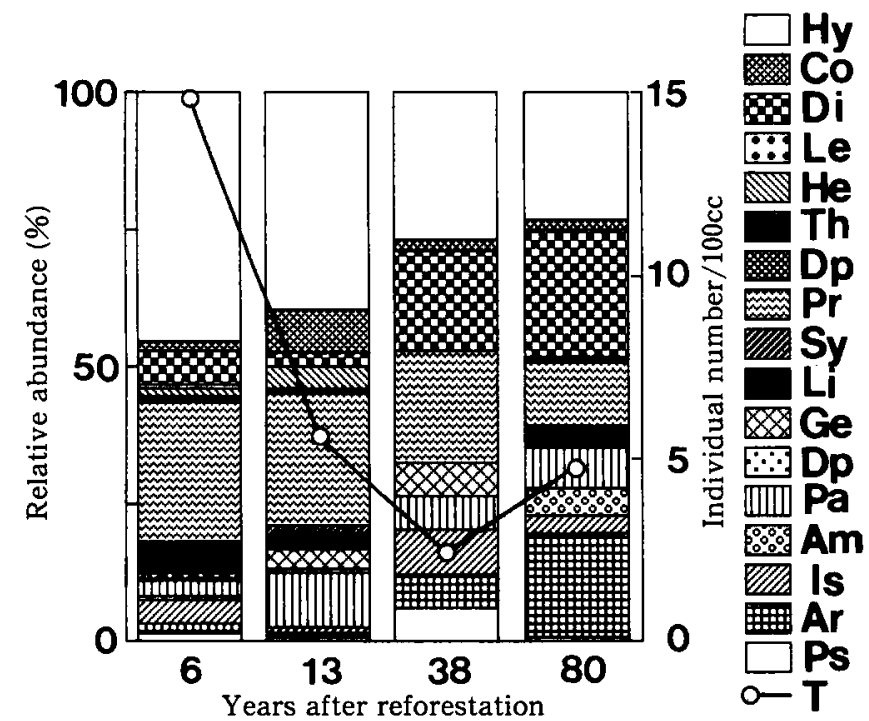

Fig. 3. Succession of soil micro-arthropods other than mites and Collembola.

Bar graphs mean population ratios among the groups. Line graphs mean total number. Hy: Hymenoptera, Co: Coleoptera, Di: Diptera, Le: Lepidoptera, He: Hemiptera, Th: Thysanoptera, Dp: Diplura, Pr: Protura, Sy: Symphyla, Li: Lithobiomorpha, Ge: Geophilomorpha, Dp: Diplopoda, Pa: Pauropoda, Am: Amphipoda, Is: Isopoda, Ar: Aranea, Ps: Pseudoscorpiones. 
Table 1. Oribatid mites found in study sites using the Tullgren funnels.

Figure means individual number per $2,000 \mathrm{ml}$ (20 samples)

\begin{tabular}{|c|c|c|c|c|c|}
\hline Species & Site I & Site II & Site III & Site IV & Total \\
\hline Zachvatkinelia nipponica & 1 & & & & 1 \\
\hline Aphelacarus acarinus & 1 & 1 & 1 & & 3 \\
\hline Palaeacarus histricinus & 15 & 4 & 4 & 8 & 31 \\
\hline Mesoplophora pulchra & 4 & & & 2 & 6 \\
\hline Hoplophthiracarus foveolatus & & & 44 & 11 & 55 \\
\hline Metaphthiracarus bacillatus & 4 & & & 2 & 6 \\
\hline Paraphthiracarus sp. & 1 & & & & 1 \\
\hline Oribotritia fennica & 8 & & & 2 & 10 \\
\hline Rhysotritia ardua & 40 & 21 & 146 & 46 & 253 \\
\hline Eohypochthonius crassisetiger & 154 & 3 & & & 157 \\
\hline Eohypochthonius magnus & & & 6 & 1 & 7 \\
\hline Eohypochthonius parvus & 24 & 10 & 11 & 2 & 47 \\
\hline Brachychochthonius elsosneadensis & 5 & & & 3 & 8 \\
\hline Brachychochthonius hungaricus & 2 & 1 & 1 & 1 & 5 \\
\hline Brachychochthonius jugatus & 6 & 9 & 1 & & 16 \\
\hline Brachychochthonius spp. & 17 & 15 & 1 & 1 & 34 \\
\hline Brachychochthonius zelawaiensis & & & 1 & & 1 \\
\hline Liochthonius spp. & 47 & 30 & 35 & 64 & 176 \\
\hline Pterochthonius angelus & & 2 & 4 & 1 & 7 \\
\hline Mixacarus exilis & 6 & 4 & 4 & 20 & 34 \\
\hline Papillacarus hirsutus & 5 & 28 & 12 & & 45 \\
\hline Apolohmannia gigantea & & 3 & & 3 & 6 \\
\hline Epilohmannia ovata & 1 & & 2 & & 3 \\
\hline Epilohmannia pallida pacifica & 1 & 6 & 7 & 3 & 17 \\
\hline Epilohmanoides esulcatus & 2 & 3 & & & 5 \\
\hline Camisia segnis & & 5 & & & 5 \\
\hline Malaconothrus japonicus & & & & 3 & 3 \\
\hline Malaconothrus pygmaeus & & 1 & 8 & 37 & 46 \\
\hline Trimalaconothrus hakonensis & 1 & & & 1 & 2 \\
\hline Cyrthermannia parallela & 6 & 4 & 1 & 3 & 14 \\
\hline Masthermannia hirsuta & 6 & 2 & 17 & 35 & 60 \\
\hline Damaeoidea sp. T-1 & 9 & 5 & 6 & 4 & 24 \\
\hline Damaeoidea sp. T-2 & 10 & & & & 10 \\
\hline Eremulus avenifer & 1 & & & & 1 \\
\hline Fosseremus quadripertitus & 88 & 4 & 16 & 46 & 154 \\
\hline Eremobelba japonica & 11 & 10 & & & 21 \\
\hline Eremobelba sp. & 7 & 8 & & & 15 \\
\hline Eremobelbidae sp. & 5 & & 1 & & 6 \\
\hline Liacarus nitens & 7 & & & & 7 \\
\hline Ceratoppia bipilis & & 3 & 2 & & 5 \\
\hline Ceratoppia quadridentata & 3 & & 1 & & 4 \\
\hline Archegocepheus nakatamarii & 16 & & & & 16 \\
\hline
\end{tabular}


Table 1. Continue

\begin{tabular}{|c|c|c|c|c|c|}
\hline Species & Site I & Site II & Site III & Site IV & Total \\
\hline Carabodes bellus & 1 & & & & 1 \\
\hline Carabodes peniculatus & 1 & & & & 1 \\
\hline Carabodes sp. 1 & 1 & & & & 1 \\
\hline Tectocepheus spp. & 47 & 140 & 31 & 2 & 220 \\
\hline Archoppia arcualis & & 1 & & & 1 \\
\hline Machuella ventrisetosa & 18 & 3 & 3 & 4 & 28 \\
\hline Oppia sp. T-1 & 8 & 19 & 2 & 46 & 75 \\
\hline Oppia sp. T-2 & 16 & 19 & & & 35 \\
\hline Oppia sp. T-3 & & 17 & & & 17 \\
\hline Oppia sp. T-4 & & 1 & 1 & & 2 \\
\hline Oppia sp. T-5 & 1 & 2 & & 9 & 12 \\
\hline Oppia sp. T-6 & 2 & & & & 2 \\
\hline Oppiella nova & 47 & 15 & & 5 & 67 \\
\hline Quadroppia quadricarinata & 110 & 41 & 22 & 39 & 212 \\
\hline Suctobelbella spp. & 161 & 134 & 70 & 110 & 475 \\
\hline Suctobelbila tuberculata & 18 & 19 & 3 & 2 & 42 \\
\hline Peloribates rangiroaensis asiaticus & 1 & & & & 1 \\
\hline Oripoda sp. & & & 7 & 7 & 14 \\
\hline Oribatulidae sp. & 1 & & & & 1 \\
\hline Tuberemaeus sp. & & & 1 & & 1 \\
\hline Xylobates sp. T-1 & 81 & 13 & 4 & 1 & 99 \\
\hline Xylobates sp. T-2 & 1 & 1 & & & 2 \\
\hline Rostrozetes foveolatus & 20 & 35 & 2 & & 57 \\
\hline Scheloribates sp. T-1 & 197 & 7 & & & 204 \\
\hline Scheloribates sp. T-2 & 73 & 5 & 2 & & 80 \\
\hline Scheloribates sp. T-3 & & 4 & 3 & & 7 \\
\hline Neoribates roubali & & 3 & & & 3 \\
\hline Trichogalumna altera & 2 & & & & 2 \\
\hline Trichogalumna intermedia & 19 & 2 & & & 21 \\
\hline Trichogalumna nipponica & 4 & & & & 4 \\
\hline
\end{tabular}

analyzed using Morisita's similarity index $\mathrm{C}_{\lambda}$. The results of similarities are clustered using Mountford's method (Mountford, 1962) (Fig. 5).

Fig. 5A shows that the community structure of oribatid mites gradually changes after reforestation, with mutual similarities being relatively low. But, the communities including the oribatid mites inhabiting the cryptomeria needles were divided into two groups, young forests and old forests (Fig. 5B). The difference is caused by H. foveolatus which lives in cryptomeria needles only in the old forests.

Dominant species (over 5\%) were Liochthonius spp., $R$. ardua, Eohypochthonius crassisetiger Aoki, Tectocepheus spp., Suctobelbella spp., Quadroppia quadricarinata (Michael), Fosseremus quadripertitus Grandjean and Scheloribates sp. T-1.

E. crassisetiger and Scheloribates. sp. T-1 were recovered only in the 6- and 13-year-old 


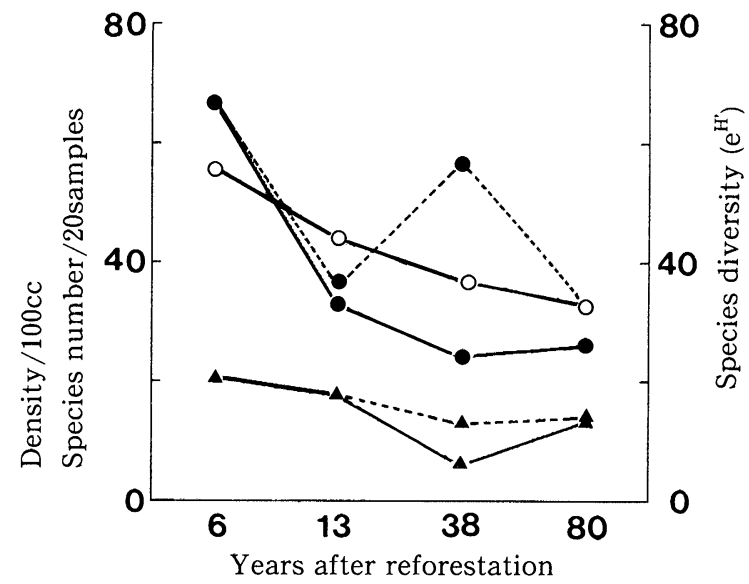

Fig. 4. Population densities and diversities of oribatid mites after reforestation.

: population density per $100 \mathrm{ml}, \mathrm{O}$ : species number, $\boldsymbol{\Delta}$ : Sheldon's species diversity $\left(\mathrm{e}^{\mathrm{H}^{\prime}}\right)$. Broken line means only collection using the Tullgren funnels.

Line means including the species boring into needle litter.

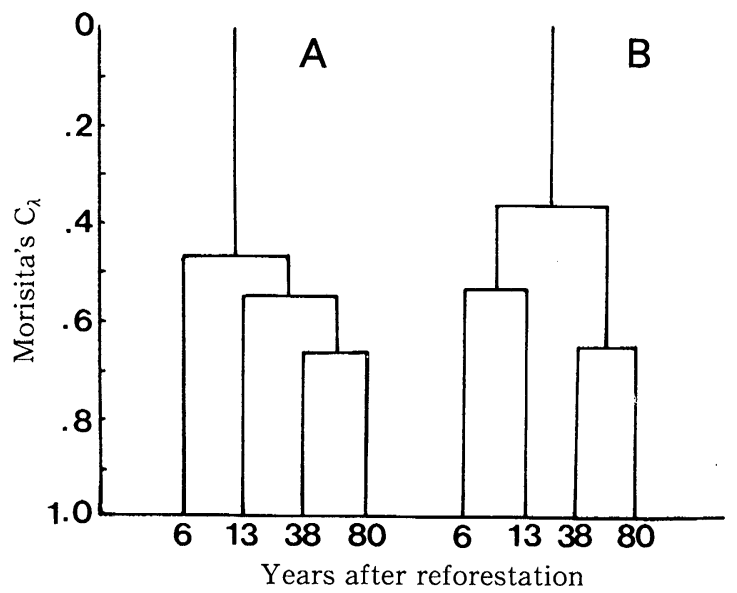

Fig. 5. Similarities of oribatid communities among study sites (Morisita's $\mathrm{C}_{\lambda}$ index, dendrograms were drown using Mountford' method).

Left: Collection using the Tullgren funnels, Right: Include boring species into needle litter.

forests (Fig. 6D). The number of Q. quadricarinata and Suctobelbella. spp. were distributed as did the total oribatid mites (Fig. 6A). Tectocepheus. spp. peaked in the 13year-old forest (Fig. 6E), but on the contrary F. quadripertitus was at its lowest level there (Fig. 6E). Liochthonius spp. was most plentiful in the 80-year-old forest (Fig. 6C) 


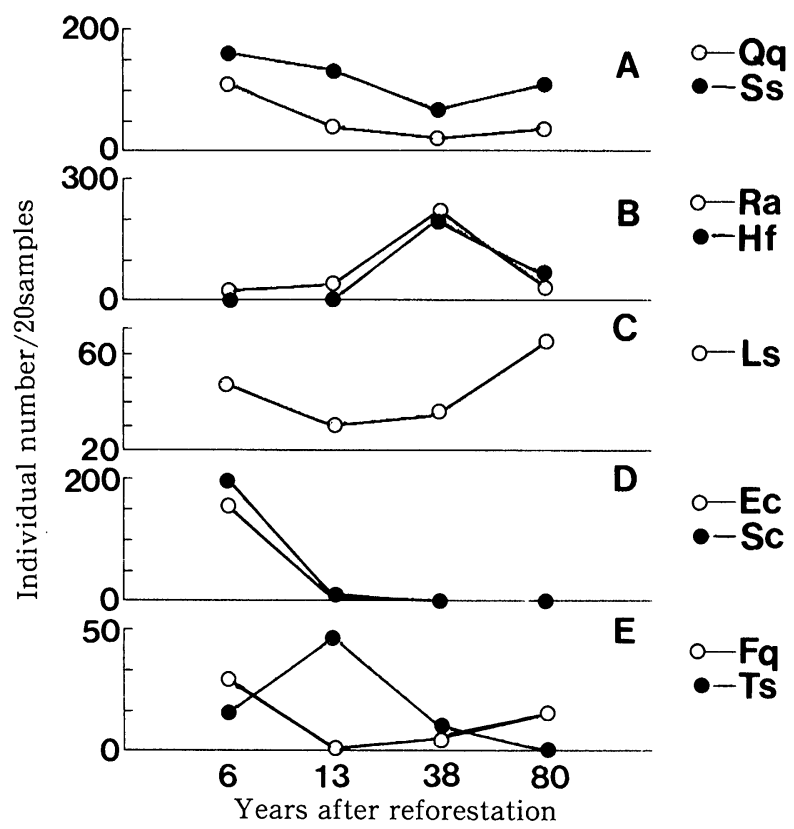

Fig. 6. Distribution patterns of dominant oribatid mites among study sites.

Qq: Quadroppia quadricarinata, Ss: Suctobelbella spp., Ts: Tectocepheus spp., Ra: Rhysotritia ardua (include individual boring in needle), Hf: Hoplophthiracarus foveolatus (include individual boring in needle), Ls: Liochthonius spp., Fq: Fosseremus quadripertitus, Ec: Eohypochthonius crassisetiger, Sc: Scheloribates sp. -T1.

and $R$. ardua was at its highest level in the 38-year-old forest (Fig. 6B).

The distribution of two congenial oribatid species exchanged with each other during reforestation. E. crassisetiger was only distributed in 6- and 13-year-old forests and disappeared in the 38- and 80-year-old forests. In contrast, E. magnus was not distributed in the 6- and 13-year-old forests but appeared in the 38- and 80-years-old forests (Fig. 7A). Similar phenomena were observed in other several groups, Oppia, Nanhermanniidae, Scheloribates and Lohmanniidae (Fig. 7B-7E).

3 ) Comparison of oribatid mites community boring in cryptomeria needle litter among the study sites

Four oribatid species were found on needle leaf litter of $C$. japonica. The dominant species were $R$. ardua and $H$. foveolatus. Phthiracarus japonicus Aoki and Oripoda sp., were rare.

$H$. foveolatus was only distributed in the 38 - and 80 -year-old forests but $R$. ardua were found in all forests. The relative abundance of $H$. foveolatus reached at its highest in the 80 -year-old forest and that of $R$. ardua was highest in the 6-year-old forest. $P$. japonica was found in the 13- and 38-year-old forests, and Oripoda. sp. was found in the 13-, 38- and 80-year-old forests (Fig. 8). 


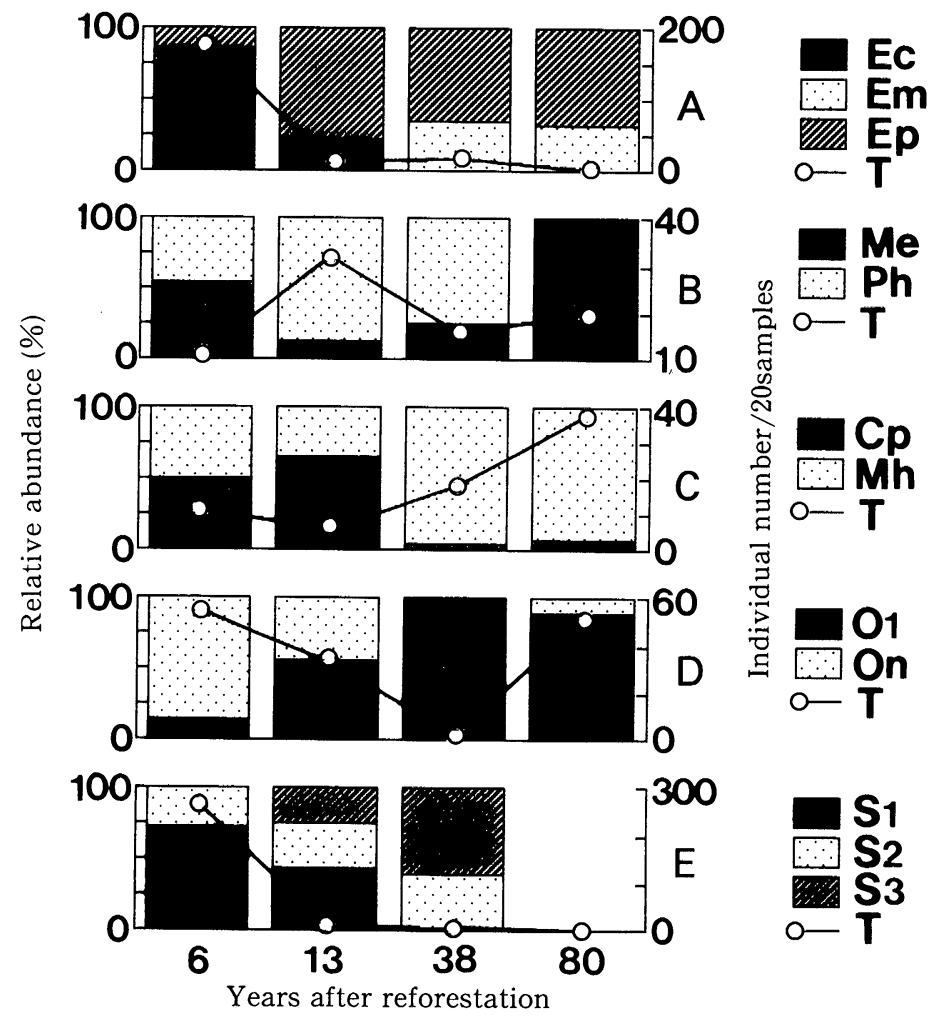

Fig. 7. Exchang of the similar species of oribatid mites after reforestation.

Ec: Eohypochthonius crassisetiger, Em: E. magnus, Ep: E. parvus, Me: Mixacarus exilis (Lohmanniidae), Ph: Papillacarus hirsutus (Lohmanniidae), Cp: Cyrthermannia parallela (Nanhermanniidae), Mh: Masthermannia hirsuta (Nanhermanniidae), O1: Oppia sp. T-1, On: Oppiella nova, S1: Scheloribates sp. T-1, S2: S. sp. T-2, S3: S. sp. T-3, T: Total individual number.

Boring rates (the ratio of the number of oribatids boring needles to the number of dissected needles) of $H$. foveolatus and $R$. ardua in cryptomeria needles litter also gradually increased after reforestation and were highest in the 38-year-old forest and decreased in the 80-year-old forest (Fig. 8).

\section{DISCUSSION}

1. Relationship between fluctuation patterns of oribatid fauna after reforestation and environmental factors

The densities of micro-arthropods in the 6-year-old forest (site I) was higher than the 80-year-old forest (site IV). In site I, there was an 80-year-old cryptomeria plantation before reforestation, and the old forest was clear-cut 7 years before. This fact means that most of the soil micro-arthropods increased 6 years after clear-cutting. In Finland, 


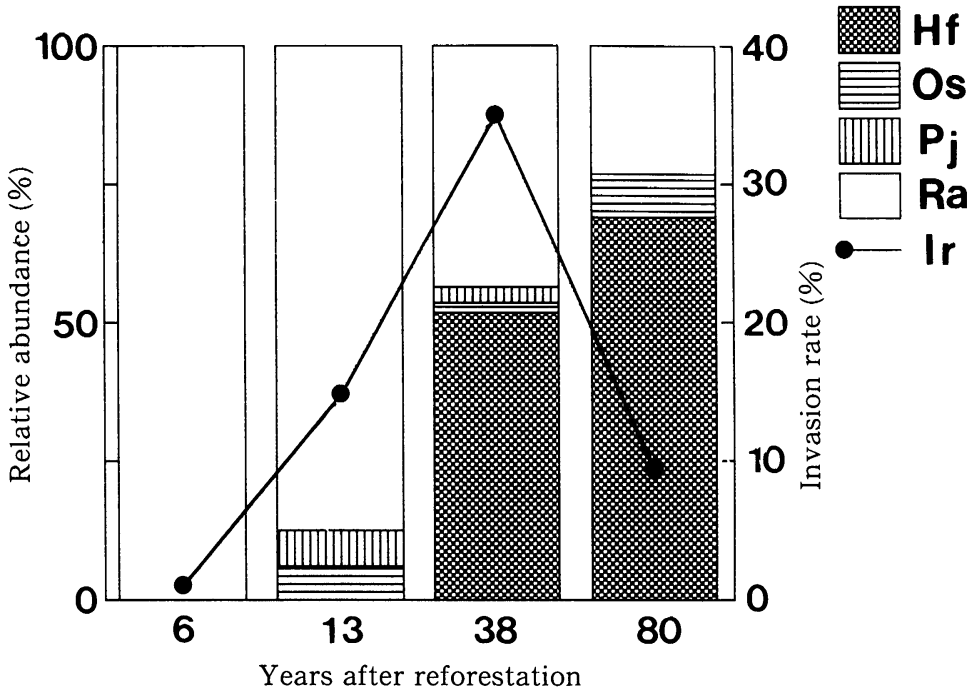

Fig. 8. Relative abundance and invasion rate of oribatid mites boring into needle litter of Cryptomeria japonica.

Bar graphs mean population ratios among the species. Line graphs mean invasion rate into needle litter. Hf: Hoplophthiracarus foveolatus, Os: Oripoda sp., Pj: Phthiracarus japonicus, Ra: Rhysotritia ardua.

the densities of Collembola and mesostigmatid mites increased 6 years after clearcutting but that of oribatid mites apparently decreased 6 years after clear-cutting (Huhta, 1976). In site I, branches being clear-cut of cryptomeria and broad leaved trees were still remained (Takahashi et al., 1988). Therefore, the mass of litter might be larger than in the case of ordinary clear-cutting where branches were completely removed. One of the reasons for the increase in oribatid population after clear-cutting in site I is the larger mass of soil litter than site IV (Fig. 1).

The distribution pattern of the dominant groups of soil micro-arthropod communities was closely related to the mass of soil litter except for cryptomeria needles (Fig. 1). This fact suggests that the density of soil micro-arthropods is affected by the mass of soil litter. Fujita et al. (1976) also concluded that the density of oribatid mites is related to the mass of soil organic materials. This conclusion is supported by the fact that the dominant group of soil micro-arthropods mainly inhabit soil litter, organic materials and the fungi colonizing on soil litter.

The distribution pattern of each oribatid species, however, was varied and was divided into several types (Fig. 6). The type 1 is the population densitiy gradually decreasing until lowest in the 38-year-old forest (Fig. 6A). This type seems to be related to the mass of soil litter other than cryptomeria litter (Fig. 1), and dominant species being Q. quadricarinata and Suctobelbella spp..

The pupulation density of the type 2 gradually increases until it peaks in the 38 year 
forest (Fig. 6B). The pattern of this type is clearly opposite to the type 1 , and is related to the mass of cryptomeria needle litter (Fig. 1). The dominant species of the type 2 were $R$. ardua and $H$. foveolatus that inhabit in abundance of needle litters.

The type 3 , the density slightly decreases to a low in the 13-year-old forest and then increases as time goes by (Fig. 6C). The dominant species is Liochthonius spp.. The distribution pattern of this type is very similar to that of the water contents of soil (Fig. 1). This fact suggests that the type 3 is sensitive to physical environment factors such as moisture.

The type 4, the density is highest in the young plantation (Fig. 6D) and clearly decreased after reforestation. The relative abundance of Poronota (major taxonomic groups of oribatid mites) in the type 4 is higher than the other types, and Poronota inhabit open and dry conditions such as grassland (Aoki, 1973, 1983).

The reason for the decrease of species diversities in oribatid mites after reforestation (Fig. 4) might be the tree species simplification and the decrease of habitat diversities in the soil caused by monoculture of cryptomeria.

2. Habitat segregations among congenial species and among same guild species

The exchange of the congenial species occurred during the successional process after the reforestation (Fig. 7). Karppinen (1955) reported the same phenomenon with Nothrus in hydrarch gradiation in Finland. E. crassisetiger and E. magnus morphologically resemble, and completely exchanged each other. E. parvus was distributed in all the study site (Fig. 7). This fact suggests that the relationship between $E$. magnus and $E$. crassisetiger is that of allopatric habitat segregation, and the relationship between $E$. parvus and the other two species is that of sympatric habitat segregation. Species that have the same niche could not in habit sympatrically (Elton, 1927). The body size of $E$. parvus is smaller than that of E. magnus and E. crassisetiger, and therefore, probably it use a different habitat from them.

Four species, $R$. ardua, H. foveolatus, P. japonicus and Oripoda sp., boring into cryptomeria needle litter probably belong to the same guild. They use the same resource. There might be competitive relationship among them. The relative abundances of the two dominant species also exchange during the successional process (Fig. 8). But the alternation of the two species is not completely such as that observed in $E$. magnus and E. crassisetiger.

H. foveolatus is monophagous and oviposits only on cryptomeria needle litter and larva bores in and grows to adulthood inside the needle (Kaneko, 1990). This species completely depends on the cryptomeria needle litter and can not survive after clearcutting because of a lack of habitat resources. On the contrary, $R$. ardua is polyphagous and widely distributes in various environments (Aoki, 1973; Harding and Stuttard, 1974). This species probably remained by feeding on various organic materials such as grass litter, twigs and wood on the ground in the young forests.

Kaneko (1990) reported that the needle litter which fell on the forest floor within a half year, was mostly bored by $H$. foveolatus and was not bored by $R$. ardua. R. ardua was found rather on the old needle litter in the present investigation. It seems that $H$. foveolatus uses the relatively fresh needle litter and $R$. ardua uses the relatively old 
needle litter after falling. It seems like that the time lag of boring period in needle litter makes them possible to cohabit in the same resource.

Though the relative abundance of $P$. japonicus was low in this study, it is a uniquely dominant species which bores into pine needles in the alpine zones (Soma, 1983). The fact might suggest the competitive relationship between $P$. japonicus and the other members of the same guild. But, further studies are necessary to make clear the habitat segregation in oribatid community.

\section{Role of boring oribatid mites on decomposition of litter}

Although the total individual number of oribatid mites collected by the Tullgren funnels was lowest in the 38-year-old forest, the total number of oribatid mites including those boring in cryptomeria litter increased to the 38-year-old forest. The number of oribatid mites in the needles was three times those collected using the Tullgren funnels, and the percentage of bored needles was over 35\%. Invasion rate in the needles in Shimane Pref., Japan (Kaneko, 1990) was over $40 \%$ and that in abies needles in France was $50 \%$ (Lions and Gourbière, 1988). Those suggest that the estimation of the role of oribatid mites on decomposition using the Tullgren funnels is insufficient. The role of the boring oribatid species on decomposition is probably more important than expected, especially in coniferous forests.

Fig. 9 show that the invasion rate of boring oribatid mites was relatively high when the mass of cryptomeria litter was large $(\mathrm{N}=4, \mathrm{r}=0.738)$. It probably means that oribatid mites regulate the decomposition rate depending on the mass of litter and keep the level of the remaining litter mass in equilibrium degree. But, the sample size was small and there was no significant correlation. Therefore, further experimental and field studies should be carried out in future.

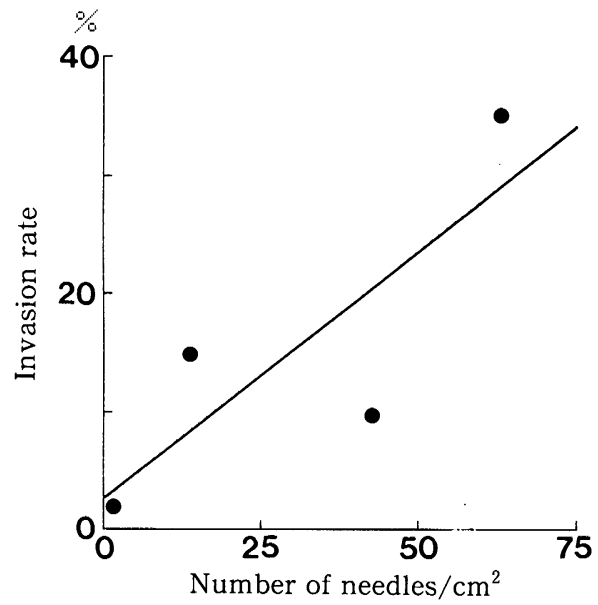

Fig. 9. Relationship between the mass of needle litters of Cryptomeria japonica and the invasion rates of boring oribatid species.

$\mathrm{X}$ axis: Number of needles per $\mathrm{cm}^{2}, \mathrm{Y}$ axis: Invasion rate, $(\mathrm{N}=4$, correlation coefficient $=$ 0.738 , N.S.). 


\section{Acknowledgments}

The authors wish to thank Dr. K. Maeto and K. Ozaki, of the Hokkaido Research Center, Forestry and Forest Products Research Institute for their useful suggestions and correction to this manuscript.

摘 要

造林後のスギ人工林における土壤中およびスギ針葉リター中のササラダニ類の遷移 福山 研二（森林総合研究所北海道支所）・伊藤雅道（森林総合研究所森林生物部）

筑波山の植栽後 6 年, 13 年, 38 年, 80 年のスギ人工林の土壌中とスギリター中に穿入して いるササラダニ相および中型土壌動物相を比較調查した。その結果, 中型土壤動物の密度は 植栽後 6 年が最も高くその後減少し 38 年目で最も低くなった。ササラダニの主要種の変動 パターンは土壌の未分解有機物量と関連するもの，水分条件に左右されるむの，スギの針葉 リターの量と相関しているあの, 植栽後の年数に関連している4つのタイプに分けられた。 近似種間で植栽後の経過にともなう分布の交替がみられた。スギの針葉リタ一中に穿入して いたのは 4 種おり Rhysotritia ardua, Hoplophthiracarus foveolatus の 2 種が優占種であっ た。

\section{REFERENCES}

Aoki, J. (1973): Soil zoology. Hokuryuukan, Tokyo. (In Japanese)

Aoki, J. (1983): Analysis of oribatid communities by relative abundance in the species and individual numbers of the three major groups (MGP-Analysis). Bull. Inst. Envir. Sci. Tech., Yokohama National Univ., 10(1): 171-176. (In Japanese)

Elton, C.S. (1927): Animal Ecology. (reprint) Chapman and Hall, London.

Fujita, N., T. Niside and J. Aoki (1976): Vertical distribution of oribatid mites on Mt. Mitsu-toge, Central Japan. Acta Arachnol., 27: 16-30. (In Japanese)

Fukuyama, K. (1974): Effects of clear-cutting on Oribatid mites (Acari: Cryptostigmata) in Japanese Cypress (Chamaecyparis japonicus) forest I. Quantitative comparison. Edaphologia, 10: 15-24. (In Japanese)

Harding, D. J.L. and R. A. Stuttard (1974): Microarthropods. In: Biology of Plant Litter Decomposition (ed., Dickinson, C. H. and F.J.F. Pugh), pp. 489-532, Academic Press, London.

Huhta, V. (1976): Effects of clear-cutting on numbers, biomass and community respiration of soil invertebrates. Ann. Zool. Fennici. 13: 63-80.

Huhta, V., E. Karppinen, M. Nurminen and A. Valpas (1967): Effect of silvicultural practices upon arthropod, annelid and nematode populations in coniferous forest soil. Annal. Zool. Fennici, 4: 87-143.

Huhta, V., M. Nurminen and A. Valpas (1969): Further notes on the effect of silvicultural practices upon the fauna of coniferous forest soil. Ann. Zool. Fennici, 6: 327-334.

Kaneko, N. (1990): Decomposition process of needle litter of Japanese Red Cedar (Cryptomeria japonica) by oribatid mites. J. Jpn. For. Soc. 72(2): 158-162. (In Japanese)

Karppinen, E. (1955): Ecological and transect survey studies on Finnish Camisiids. Ann. Zool. Soc. 'Vanamo', 17: 1-80.

Karppinen, E. (1957): Die Oribatiden-Fauna einiger Schlag- und Brandflachen. Suomen Hyonteistieteellinen Ailalauskirja, 23(4): 182-203. 
Lion, J.C. and F. Gourbière (1988): Populations adultes et immatures d'Adoristes ovatus (Acarien, Oribate) dans les aiguilles de la litiere d'Albies alba. Rev. Ecol. Biol. Sol., 25(23): 343-352.

Morisita, M. (1959): Measuring of interspecific association and similarity between communities. Mem. Fac. Sci. Kyushu Univ. Ser. E. (Biol.) 3(1): 65-80.

Mountford, M. D. (1962): An index of similarity and its application to classificatory problem. In: Progress in Soil Zoology (P. W. Murphy, ed.), pp. 43-50, Butterworths, London.

Sheldon, A.L. (1969): Equitability indices dependence on the species count. Ecol., 50: 266-467.

Soma, K. (1983): A preliminary study on the feeding activity of micro-arthropods in needles of Pinus pumila on the forest floor. Report of Fundamental study of Alpine ecosystem in Central Mountainous area in Japan II. p. 10-12. (In Japanese)

Takahashi, M. and K. Niijima (1988): Effects of slash in the clear-cut area of Sugi (III) Slash decomposition process and soil animals. Trans. 99th Annu. Meet. Jpn. For. Soc., 211-212. (In Japanese)

Wallwork, J. A. (1976): The Distribution and Diversity of Soil Fauna, pp. 355, Academic Press, London.

Watanabe, H., 1973: Effect of Stand Change on Soil Macro Animals. J. Jpn. For. Soc. 55(10): 291-295. 